\title{
LSP1 wt Allele
}

National Cancer Institute

\section{Source}

National Cancer Institute. LSP1 wt Allele. NCI Thesaurus. Code C68714.

Human LSP1 wild-type allele is located in the vicinity of 11p15.5 and is approximately 39 $\mathrm{kb}$ in length. This allele, which encodes lymphocyte-specific protein 1, may be involved in the regulation of neutrophil motility, adhesion, and transendothelial migration. 